\title{
HYPERCOMPLEX KNOWLEDGE IN A KNOWLEDGE-BASED ECONOMY²
}

\section{Abstract}

The paper provides a definition of hypercomplexity and hypercomplex knowledge in knowledge-based economies and proves the hypothesis that development, application and expansion of new technological achievements have a direct impact on a country's economic growth. Data collected from relevant databases for 110 world countries were used in the calculations. Data for other countries have not been published, which is a typical limitation in the application of such research methodology. Developmental lags of the Republic of Croatia have been established by the method of transformation of variables in the analysed developmental indicators and their components, and proposals for their improvement have been provided. Taking into consideration the established effect of the increase in the Research Capacity Development Index, Technology and Innovation Efficiency Index, and the Ability to Absorb Knowledge and Technology Index on economic growth, Croatia needs to invest additional resources in the increase in human capital and labour productivity in order to reduce developmental lags.

Keywords: hypercomplexity, knowledge, knowledge economy, human resources development, economic growth and development

JEL classification: 010, 015, 033, D83

\section{Introduction}

New economic development is a consequence of scientific-technological revolution and has resulted in changed significance of certain production factors and emergence of the new economic development factors. Knowledge, labour, capital, and later management (organisation) were considered primary resources in the economic science until the occurrence of the third scientific-technological revolution. In the framework of the new science, it is deemed that information, space and time have become new factors of economic development (Pulić, 1998, 25). Besides, production factors management has become more important than their owning. Physical jobs have become fully mechanised, intellectual management increasingly cyberneticised, energy, space and time mastered, new scientific disciplines have emerged, the number of investments in scientific research has been increasing, and the time period from scientific research to application of the discovery has become shorter. (Sundać, 1997, 9-13) Great changes in the field of scientific research have led to shorter duration of acquired knowledge, and this causes the necessity for permanent education. The gap between developed and underdeveloped countries has been increasing. All of these consequences of the third technological revolution have been significantly influenced by globalisation, information as the basic knowledge unit, and networking. Free, transnational flow of ideas, information, knowledge, human resources, goods, and capital has created a new technological and overall

development direction. Development of new technologies leads to increasingly higher share 1 PhD,University of Rijeka, Faculty of Economics, Senior Assistant, zoran.jezic@efri.hr

2 This article is the result of the scientific project Human Resources and Economic Development of Croatia (081-0811403-1409) financed by Croatian Ministry of Science, Education and Sports 
and significance of knowledge, education, and new skills.

Rapid obsolescence of existing knowledge and application of new knowledge, as a foundation of hypercomplex knowledge, require permanent education of human resources. They should be constantly trained for development, application and use of new technologies. Trained human resources enable technological progress and development; application and expansion of new technological achievements are the necessary preconditions for competitiveness in developed societies, by which they have a direct impact on a country's economic growth.

The objective of the paper is to define hypercomplexity in knowledge-based economies, and establish the position of the Republic of Croatia in the global environment on the basis of analysis of research capacity development, technology and innovation efficiency and the ability to absorb knowledge, as well as to propose the basic developmental guidelines.

\section{THEORETICAL AND METHODOLOGICAL ASSUMPTIONS WITH LITERATURE OVERVIEW}

\subsection{LITERATURE OVERVIEW}

Knowledge economy is a predominantly electronic economy based on information, knowledge, and new skills (Godin, 2010, 261). Information have become the basic value in the circulation of goods on the world global market, and their possession or non-possession is always reflected in trade characteristics. Possession or non-possession of information has become the new source of power. Information are disseminated by global communication networks which have determined an economic shift: from industrial to information economy. Attention should be devoted to difference between information industry (production of hardware, software and orgware), and information industry based on information and its installation in each service and goods. Establishment and expansion of communication networks and their horizontal and vertical connections have brought down hierarchical structures of industrial society, classic Tayloristic organisation, and centralised social institutions have become disputable. It may be concluded that, in the past decade, high technology increase in the world trade has been accelerating, and that it resulted in the following: promotion of creativity and innovativeness, stimulation of interdisciplinary and multidisciplinary approach to research; organisational structure changes in order to increase effectiveness; linking of knowledge and economy through faster commercialisation of results; collecting of scientific and financial resources through (transnational) megaprojects, development of research- and educational capacity, increased number of investments in research. The above has occured as a consequence of the following proccesses: organised and permanent collection of knowledge and creation of knowledge databases, rapid and organised creation of new knowledge; increase in the ability to absorb knowledge, improvements of communication infrastructure for more effective access to knowledge and its exchange by creating computer networks, finding of effective organisational models of application of the acquired knowledge («learning enterprise»), by developing new branches of science (biomedicine and genetics, biotechnology, nanotechnology...), by emergence of new materials and new forms of energy...(Strategija razvitka Republike Hrvatske Hrvatska u 21. stoljeću, 2003) The above-mentioned stimulates sociocultural transition from an industrial 
society to knowledge society, and economies to knowledge-based economies.

On the existing developmental level of science, technology, also human society, investment in human resources education has become one of the most important investments for modern development. This is proven by the fact that only about $15 \%$ of the world countries are highly developed, and their share in the world wealth amounts about $80 \%$ (the World Bank, 2005). Economy of scale is no longer significant in the global economy. New obstacles to penetration of new companies to a knowledge economy are not a matter of scale, but rather of high value and quality production. Knowledge economy is based on specialised knowledge, primarily on the skill of linking, identifying and solving problems. Such skilled employees have the following qualities: multi-education, independent initiative, creativity, communication, sense of responsibility, co-operativeness, comprehension of technologies and the environment. Innovativeness and creativity have become the ability of managers to act strategically, to create alliances, and to stimulate development and changes.

One should take into consideration the fact that changes in the structure of modern economics, new possibilities and challenges have been elaborated on in various theories on post-industrial economy and society, while pointing out different contents and using different names. According to this approach, the first theoretician who used the name «knowledge economy» is Peter Drucker, together with Marien («classic industry has been replaced by new forms of post-industrial activity»), Huntington (the "postponed society» theory), Crozier («entropy state»), Boulding (post-civil society theory), and Mumford («the age of equilibrium»). According to Drucker, knowledge economy and national knowledge-based economy differ from traditional economies by the fact that: information becomes a basic shareable resource and its value rises with use; location of the economy becomes irrelevant - the market becomes virtual; laws, regulations and taxes are no longer of national significance; knowledge and information are transferred where demand is the greatest, and obstacles the smallest; prices become a matter of context and the same product and service may be charged differently every time; human resources become the basic value of knowledge economy. (Drucker, 1992) Knowledge management in a knowledge-based society becomes a success strategy focused on the rational, i.e. effective and efficient use of knowledge as an important non-material resource in contemporary manufacturing and service processes. Efficient use of knowledge has become a necessary precondition for realisation of economic strategy - economic development. Interrrelation between educational and economic (entrepreneurial) subsystem implies such a relationship, in which, in systematic terms, educational system produces an information output by which the economic system attempts to fulfill its information needs in the production field.

A new economic view which emerged at the beginning of the 1990s rejected traditional hypotheses which implied that economy was a closed, balance-reaching system. Theoreticians of hypercomplexity deem that national economies and societies are a complex, adaptive, endogenous system. Hypercomplexity implies great complexity of a society, company, organisations, and science (Qvortrup, 2004a: 2). It is considered one of the «four c's» for the new paradigm in the field of economics (Antonelli, 2011) The «four c's»: complexity, chaos, catastrophe, cybernetics»). 
Hypercomplexity annulls many aspects of traditional economic theory. Namely, mathematical models used by traditional economy are based on system balance. Advocates of (hyper) complexity of economics claim that traditional economic models have never been adjusted to the latest discoveries and thus remained incomplete models of reality, and emphasise the significance of introduction of information entropy in the economic models. Entropy has been used since 1988 in formulating of important concepts of organisation and simulation of development of complexsystems, including economic systems. Traditional economic models have been set up by allowing only a very small degree of freedom, for reasons of model simplification. For example, the relationship between unemployment and inflation has traditionally been considered a simple function with a single freedom degree, which provides very little entropy. "The sciences of the complexity redefine from scratch the relationships between science and society." (Agguerrondo, 2010:3)

It is deemed that hypercomplexity (Rutenbeck, 2006) is based on behavioural, institutional and evolution economy, and complexity includes components from each of these fields of economics. Behavioural economics (BE) is defined as a discipline which uses insights on social, cognitive, and emotional phenomenons in the impact of people's economic behaviour. The BE has linked the disparity of economic theories and real behaviour, which has reflected in insufficient predictability. Psychology, especially cognitive and social, has contributed to improvement of ecological validity - reality - of economic models whose estimates are based on mathematical axioms and formalisations (from which conclusions are derived on reasoning in the decision-making process). The latest field of behavioural economics is neuroeconomics, a discipline which combines neurology, psychology, and economics, and refers to research of brain activities during financial decision-making and behaviour. Neuro-correlations of inclination and avoidance of risk have already been recognised, and there are evidence that persons with damaged regions for the display of emotions (for example, fear) make better financial decisions. Institutional economics is interdisciplinary; found between economics and the law. This is a relationship between the state as regulator, in the wider context of drafting and execution of laws and regulations on one hand, and economic activity of entrepreneurs and economy as a whole on the other hand. Evolution economics has focused on processes which constantly introduce economic changes, thus influencing all economic entities and institutions, such as different companies or employees. These processes are a result of actions and interaction of various individuals who make the system, and are based on available information. In simple terms, this means that no social model, including the economic one, may be constant; it is subject to constant changes caused by constant innovations.

Brian Arthur, Steven N. Durlauf and David A. Lane from the Santa Fe University have defined six characteristics of (hyper)complex systems (Qvortrup, 2004b and Agguerrondo, 2010:7-9): 1. Dispersion - economic events are defined by interaction of many dispersed factors, and any factor's action depends on the expected activities of a limited number of other factors; 2. There are no global entities which control interactions. Control is ensured by mechanisms of market competition instead; 3. Economy has many levels of organisation and interaction; 
these units usually serve as «building blocks» for building of a unit on the following, higher level, on any level of activity. Total system organisation is hierarchical, with many kinds of interactions by levels; 4. Permanent adaptation - behaviour, action, strategy and products are constantly revised and the system continuously adapts; 5. New markets, new technologies, new behaviours, and new institutions are created continuously, the result of which is constant need for learning and training; 6. Because of new niches and new possibilities, economy is far from «optimal», or from global balance. This is why improvements are always possible and occur regularly. The table below shows the differences between categories and forms of knowledge complexity, and provides a definition of hypercomplexity.

\section{Table 1: Knowledge Complexity and Forms of Knowledge Complexity}

\section{Knowledge Category Knowledge Form Definition of Knowledge}

\begin{tabular}{|c|c|c|}
\hline $\begin{array}{l}\text { 1. The first class knowledge - } \\
\text { simple knowledge }\end{array}$ & Knowledge of something & $\begin{array}{l}\text { Knowledge of facts /factual } \\
\text { knowledge }\end{array}$ \\
\hline $\begin{array}{l}\text { 2. The second class knowledge } \\
\text { - complex knowledge }\end{array}$ & $\begin{array}{l}\text { Knowledge of learning } \\
\text { conditions /knowledge }\end{array}$ & Reflexive knowledge \\
\hline $\begin{array}{l}\text { 3. The third class knowledge - } \\
\text { hypercomplex knowledge }\end{array}$ & $\begin{array}{c}\text { Knowledge of reflexive } \\
\text { knowledge system conditions }\end{array}$ & $\begin{array}{c}\text { Systematic and creative } \\
\text { knowledge }\end{array}$ \\
\hline 4. The fourth class knowledge & Complex knowledge & $\begin{array}{l}\text { Synergy of knowledge of all } \\
\text { members of the society }\end{array}$ \\
\hline
\end{tabular}

Source: Made by the author, according to Qvortrup L.: The Hypercomplex Society, University of Southern, Denmark, 2004, p. 2, and Qvortrup L.: Society's Educational System, www.seminar.net

The first class knowledge represents simple factual knowledge, and the second class knowledge represents comprehending and using simple factual knowledge. Hypercomplex knowledge (or the third class knowledge) implies systematic and creative management of the existing facts and knowledge in forming of new ones. The third class knowledge has been subject of research by many modern philosophers, among others, by the French philosopher Michel Serres. According to Serres, in order to learn something, the starting point is not only what one knows in relation to what one does not know; the matter is rather in changing the outlook on learning as a creation of something new (Serres, 1995, 1-204). Foundation of the third class knowledge are scientific research, licences, patents, trademarks, and innovations. The fourth class knowledge represents a "knowledge society" as a special form of knowledge, which may not be owned by a single person, but is owned by a total social community in which all individuals are members. It is created by the synergy of knowledge of all members of narrower and wider community and is much more complex type of knowledge.

Thus, a society's hypercomplexity concept is based on the paradigm of complexity. However, «complexity» is not a new concept. On the contrary; complexity and management complexity are concepts rooted in rationalists' ideas of 18th and 19th century philosophies. However, the term of hypercomplexity of society and knowledge has been introduced by 
Herbert A. Simona, and the term has been transferred to scientific management theories in the twentieth century. He showed that modern society has been developing into a social system through social evolutions, with an important ability to manage complexity. Summary of his comprehensive analysis of social system as a whole is the following: a society develops according to polycentric and poly contextual social systems in order to manage increasingly more complex environment in the global society.

\subsection{METHODOLOGY}

Knowledge societies which base their development on the third class knowledge, i.e. hypercomplexity, develop their research capacity and are successful in the absorption of technology and knowledge. In the following section, the subject of analysis is development of research capacity, technology and innovation efficiency, and the ability to absorb knowledge in the Republic of Croatia and the selected countries.

The method of transformation of variables (Habing, 2004:1-6) is used to analyse the development level of research capacity, technology and innovation efficiency and the ability to absorb knowledge and technology. Namely, in order for all of the above-mentioned indicators to be transformed to the index which has values from zero to one, which enables their comparison and aggregation, the following formula of variable transformation and its derivative is used:

$$
x-\text { inde } x=\frac{x-\min (x)}{\max (x)-\min (x)}
$$

where $\min (\mathrm{x})$ and $\max (\mathrm{x})$ are the highest and the lowest values of the variable $\mathrm{x}$. The method of transformation of variables is used every time there is a great number of different indicators in the research which need to be reduced to a common measure, the goal of which is the possibility of their unification and facilitation of their comparison. For example, the World Bank uses the quotient of the natural logarithm of GNI per capita, reduced by the natural logarithm of the number 100 and natural logarithm of USD 40,000 as the supposed maximum value of GNI per capita in its methodology for the calculation of the GNI index as a component of the Human Development Index (HDI).

Data used for analyses below are taken from statistical publications of the United Nations for 2009 and 2010, and for reasons of comparibility, 2007 has been taken as the reference year in relation to data availability. The analysis has been conducted for 110 countries, and the most significant results for the Republic of Croatia and the selected countries have been shown in tables in the appendix to the paper. 


\section{ANALYSIS OF RESEARCH CAPACITY DEVELOPMENT, TECHNOLOGY AND INNOVATION EFFICIENCY AND THE ABILITY TO ABSORB KNOWLEDGE IN THE REPUBLIC OF CROATIA AND THE SELECTED COUNTRIES}

As stated in the theoretical and methodological part of the paper, development of innovation and technology, together with proper functioning of the educational system and research capacity development determines economic growth and development. Namely, educated employees, i.e. human capital, become agents of the creation of knowledge which enables an increase in the number of innovations, which lead to technological changes, which significantly accelerate economic growth. This interaction is subject of the analysis below by means of mathematical, statistical and graphic methods.

An increase in the share of highly educated population is a component of a long-term research capacity development strategy. Namely, research capacity has a significant impact on economic growth and development regarding direct relationship between development of human resources and innovativeness, which results in research capacity development. The Research Capacity Index is a combined index of three indicators: 1. investments in research and development, 2. investments in tertiary education, and 3. the number of scientific publications (Table 2 in the appendix to the paper).

According to the Research Capacity Index, in 2007 Israel was ranked first, followed by Sweden, Japan, the USA, Finland, Germany, Switzerland... the Republic of Croatia was ranked 32nd, and Cambodia was the last, 110th. Research and innovations help create new workplaces, achieve prosperity and quality of life. A significant deviation of the Republic of Croatia is evident in 2007 in research capacity development in comparison with highly developed countries. Namely, the Republic of Croatia lagged behind Israel by 91,07\%, behind Sweden by $82,37 \%$, and behind Japan by $76,93 \%$. Likewise, Croatia also lagged behind the neighbouring countries in research capacity development, i.e. countries which accessed the European Union in 2004. According to this indicator, Croatia lagged behind Slovenia, Poland and Hungary, which were ranked 27 th to 29 th (the average lag of 7,5\%). The Republic of Croatia achieved a better result in comparison with Slovakia (positive deviation of 10,43\%), Romania (21,42\%), and Serbia $(49,80 \%)$. In comparison with Cambodia, ranked last, measured by research capacity development, the Republic of Croatia realised a positive deviation of $99 \%$.

Although the European Union is the world leader in many technologies, it has been faced with ever greater challenges, not only by traditional competitors (Japan, the USA), but also by knowledge economies in the making (Korea, China). The main test for the European Union is to stay competitive and use science and technology with the goal to contribute to economic growth, create workplaces, quality of life and solve social challenges, such as poverty, health care and damage done to the environment. Thus, the Republic of Croatia needs to recognise the importance of investments in research and development. Lower consumption level for research and development by the private sector is the key reason for lagging behind the European Union in research capacity development. The share of R\&D business financing amounts only 1,2\% of GDP in the EU, in comparison with 1,9\% in the USA and 2,4\% in Japan. (European Union Delegation in 
Croatia, 2011) The European Union also has fewer examples of turning scientific knowledge and discoveries in patented inventions, especially those necessary for high technology industries. ( $7^{\text {th }}$ Framework program, 2010) The EU strives to eliminate these difficulties by an integrated approach to research and innovation policies, in order to implement research and development and their significance in all EU policies, from state grants to effective protection of intellectual property, from education to co-ordinated use of tax incentives for research and development promotion. However, the most concrete manifestation of the European Union's science and technology policy is forming of the European Research Area (ERA) and investment of EUR 50,5 billion (European Union Delegation in Croatia, 2011) in research capacity development until 2013.

Positive effect of research capacity has a direct impact on higher technology and innovation efficiency. Namely, more educated human resources create a greater number of scientific and professional research, the result of which is a greater number of scientific publications which contribute to the increase in the number of patents, licences and trademarks. Technology and Innovation Efficiency Index is a combined index, i.e. the mean of three indicators: 1 . the number of patents by the country's residents applied in the region; 2 . receipts from licences, and 3. the number of residents' trademarks applied in the region (Table 3 in the appendix to the paper).

Technology and innovation efficiency is measured as an arithmetical mean of receipts from licences, the number of patents and the number of trademarks. Countries are ranked according to the index level. According to the calculation of this index, the USA are ranked first, followed by Japan, Korea, and Germany. The Republic of Croatia is ranked 31st. Technology and innovation efficiency is crucial for economic growth and development, and competitiveness of countries. Measured by technology and innovation efficiency, the Republic of Croatia lags behind the most developed countries two times (99\% behind the USA, 95\% behind Japan and $76 \%$ behind Korea). Croatia also lags behind Hungary (ranked 18th), Poland (ranked 26th), and Ukraine (ranked 29th), but realises positive deviations in comparison with Slovenia (ranked 33rd), Slovakia (ranked 50th), and Serbia (ranked 52nd). According to the above indicator, Croatia is ranked 31st. The greatest positive deviation is realised by the Republic of Croatia compared to Bolivia, ranked last, on the 110th place. According to data from 2006, leaders in innovations are Sweden, Finland, Switzerland, Denmark, Japan, and Germany. Croatia groups among „trailing countries“ in terms of innovations, together with Estonia, Spain, Italy, Malta, Hungary, and Slovakia which are separated from the developed countries by followers and catching-up countries (Pro-Inno-Europe, 2006). Constant evaluation of innovation systems and innovation capacity of companies has a great role in the formulation of strategic developmental guidelines of certain countries, at least in relation to development of the small and mediumsized enterprises sector, technological transfer, inclusion of the scientific sector in economic development, lifelong learning, etc. Constant evaluation through mutual comparisons, including „competitions" of national administrations, results in deeper analyses of development and introduction of improvement measures. In order to increase competitiveness, the European Union has been financing a great number of technology and innovation research through 
the 7th Framework R\&D Programme and the Community's Competitiveness and Innovation Framework Programme (CIP) (European Union Delegation in Croatia, 2011). Until 2013, the European Union plans to invest EUR 3,6 billion ( $7^{\text {th }}$ Framework program, 2010) in small and medium-sized enterprises which strive for innovations, especially in the fields of energy efficiency and renewable energy sources, environmental technologies and improved use of information and communication technologies (ICT). The European Technological Institute was founded in 2008, and it unites three sides of the knowledge triangle in one place - research, education, and innovation, which together make a basis for knowledge-based economy. The Institute operates through communities for innovation and knowledge, which are a result of partnership between the private sector, research community and universities. Considering its considerable lagging behind in the technology and innovation efficiency, Croatia should make great efforts in order to reach EU Member States, as well as other developed countries. This should be accomplished by creating a climate which promotes innovation, which enables business entities to be competitive, and the ability to absorb knowledge will play a significant part in this process.

The ability to absorb knowledge and technology reflects in a successful difusion of new economic technologies. The Absorption of Knowledge and Technology Index is the arithmetical mean of two indicators: 1. labour force productivity and 2. GNI per capita.

The basic premise of the ability to absorb knowledge and technology is reflected in higher labour force productivity, which generates greater production, and by this higher income level. According to this indicator, the United States of America are ranked first, with the maximum index (table 4 in the appendix to the paper). The maximum index means that the United States of America have the ideal ratio of labour force productivity and the GNI. Norway, Ireland and Hong Kong have minimum deviations, following the USA. The Republic of Croatia is ranked 40th and records negative lagging behind the USA by 28,19\%. Slovenia is also ranked better than the Republic of Croatia (ranked 29th), the Czech Republic (ranked 31st), Slovakia (ranked 33rd), Hungary (ranked 35th), and Poland (ranked 38th). Among the neighbouring countries, Croatia records positive deviation in comparison with Serbia.

Although, according to the World Bank criteria, Croatia groups among highly developed countries (according to the World Bank criterion, Croatia in 2008 realised USD 16,980 per capita) (Human Development Report, 2010), and according to the OUN criterion, is one the high human resources development level (according to the World Bank criterion, Croatia in 2008 had the Human Development Index of 0,767 and groups among countries of highly developed human resources) (Human Development Report, 2010), Croatia records the greatest developmental lags in the key developmental components; the application of research capacity and efficiency and application of technology and innovation. When Croatia is compared with the neighbouring countries, its lagging behind Slovenia is especially visible in terms of research capacity development (the lag of 8,58\%). The Technology and Innovation Efficiency Index indicates Croatian lagging behind Austria (28,2\%), and Estonia (15,02\%) in terms of ability to absorb knowledge and technology. In global terms, Croatia lags behind Israel the most in research capacity development (91,08\%) and the United States of America in the ability to absorb 
knowledge and technology (28,19\%), and technology and innovation efficiency $(99,17 \%)$. Taking into consideration almost double lag in all components of development indicators in terms of highly developed countries' average, Croatia will have to invest greater efforts in order to reach highly developed countries and the EU Member States. Chart 1 shows relationship between the Research Capacity Index, Technology and Innovation Index, Ability to Absorb Knowledge and Technology Index and economic growth.

Figure 2: The Relationship between the Ability to Absorb Knowledge and Technology, Research Capacity, and Technology and Innovation Efficiency
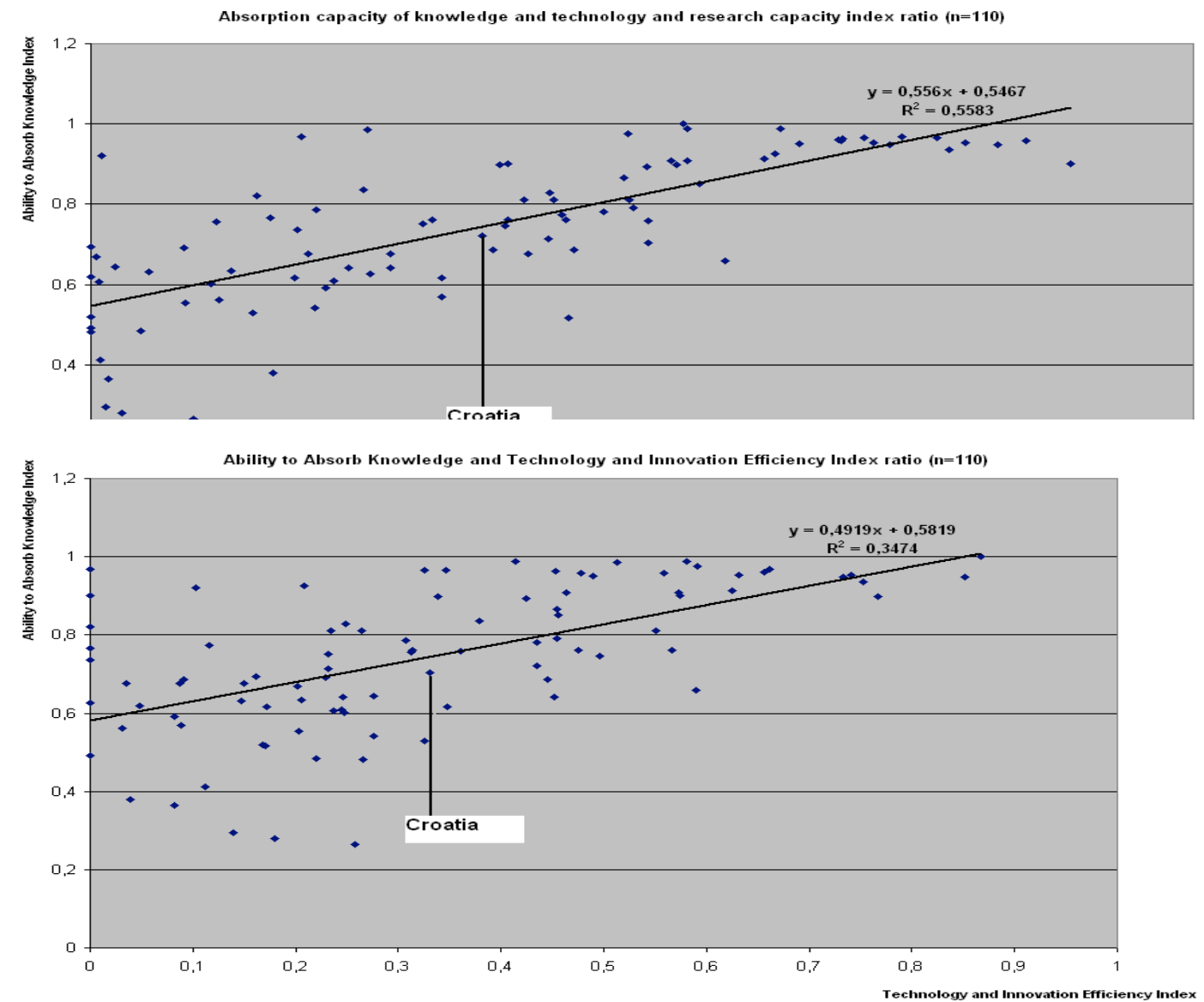

Source: author's calculation

Charts indicate a strong relationship between the increase in the Research Capacity Index, Technology and Innovation Index, and the Ability to Absorb Knowledge and Technology Index and economic growth (Chart a), but also vice versa (Chart b). In addition, charts indicate that Croatia is below the average of the countries analyzed in the development of hypercomplex knowledge Namely, taking into consideration regression determination coefficient which marks the connection between two or more variables, and which is described in the model (a) $74,71 \%$, and in the model (b) $58,94 \%$ of all points of the function, a strong connection may be established between the observed occurrences on the basis of which the following 
conclusions may be derived: reduction of the gap between the developmental level of Croatia and the developed EU Member States should also be based on an increase in the quality of the human factor, which is achieved by an increase of general health care and quality of life. At the moment when investment capital has reached enormous mobility and availability, the human quality factor has the key role in its gaining: the higher the quality, the better conditions for the import of capital, and the technology provided by this capital is of greater quality. Quality educational programmes increase the quality of education of the human factor; improvement of the ability to attract researchers and strengthening participation of female researchers support creation of the necessary preconditions for more sustainable and attractive careers in the sector of education, research and development. The necessity for specific practical knowledge and skills, and for general knowledge and skills such as interpersonal relationships and social competence, should be met by stimulating investments in research and development, by financing vocational education in Croatia which has currently been viewed in the traditional manner, by conducting a reform of vocational education. Greater investments should be made in high education. Investments in Croatia have currently been too low in comparison with European means. Life-long learning, for now primarily conducted through adult education policy, should be stimulated; examples of good practice from other European economies should be used; information and communication technology should be applied in education; various innovative approaches to learning should be stimulated.

\section{CONCLUSION}

Development of innovation and technology through proper functioning of the educational system and research capacity development system determines economic growth and development. Educated employees, i.e. human capital, becomes an agent of knowledge creation which enables an increase in the number of innovation, and they lead to technological changes which significantly accelerate economic growth. Increase in the share of highly educated population is a component of a long-term strategy of research capacity development. Dynamic coordination between science and society is achieved by making investments in their development, and efficiency of the two-sided science - society communication channel is promoted which became the foundation of hypercomplex knowledge in a knowledge-based economy.

A new economic theory, which emerged at the beginning of the 1990's, rejects traditional hypotheses which indicated that economy was a closed system which reached balance. Theoreticians of hypercomplexity deem that national economies and societies are a complex, open, adaptive, endogeonous system, and that hypercomplexity represents exceptional complexity of the society, companies, organisations and science. In such environment, taking into consideration the established correlation between an increase in the Research Capacity Index, Technology and Innovation Efficiency Index, and the Ability to Absorb Knowledge and Technology Index and economic growth, in order to reduce developmental lags, Croatia needs to invest additional resources in the increase in human capital and productivity.

The significance of a specific component of economic growth from the analysed model should be additionally established by statistical and mathematical methods, which could 
provide a possibility to precisely determine specific measures for stimulation of technology and innovation efficiency, ability to absorb knowledge and technology, as well as human resources development.

\section{REFERENCES}

Aguerrondo, I. (2009) “Complex knowledge and education competences”, UNECSO, Geneva, Switzerland

Antonelli, C. (2011) "Handbook of the Economic Complexity of Technoogical Change", Edward Elgar Publishing, University of Turin, Italy

Bagolin I. (2008) "Human Development Index - a poor representation to Human Development Approach" // http://www-1.unipv.it/deontica/ca2004/papers/bagolin.pdf (7.7.2008.)

Bagolin I. (2008) "Human Development Index (HDI) and its family of indices: an evolving critical review", Revista de Economia, Vol. 34, No. 2, p. 7-28.

Bajo, A. (2003) Financiranje visokog školstva i znanosti, Institut za javne financije, Zagreb. (Financing Higher Education and Science)

Blitzer, J. (2005) “Measuring knowledge stocks: A process of creative destruction”, Kyklos, Vol. 58 , No. 3, p. 379-393

Bujas, G. (2001) “Determinants of Economic Growth with Reference to Transitional Countries”, Proceedings of Rijeka Faculty of Economics, vol. 19., no. 2., p. 19-31

Boulding, K. (1981) “Evolutionary Economics” Sage, New York

Crouzier M.J., Huntington S.P. (1973) “The Crisis of Democracy”, New York University Press, New York

Dragičević, M. (1996) Ekonomija i novi razvoj, Alineja, Zagreb (Economics and New Development)

Drucker, P. (1992) Nova zbilja, Novi liber, Zagreb (The new reality)

Družić, I. (2004) Resursi i tržišta hrvatskog gospodarstva, Politička kultura, Zagreb, (Resources and markets of the Croatian economy)

Giovanni, E., (2002) Measuring productivity OECD Manual, Paris <http://www.oecd.org/ dataoecd/59/29/2352458.pdf>

Godin, B. (2010), «Measuring knowledge in a economy in terms of triple-helix relations in The Capitalization of Knowledge», Edward Elgar Publishing

Habing, B (2004), «Transformation of Varaibles», University of South Carolina, USA

Human resource development in a knowledge-based economy (2003), The Emirates Center for Strategic Studies and Research, Abu Dhabi, United Arab Emirates

Lengnick-Hall, M.L. (2003) «Human Resource Management in the Knowledge Economy», Berrett-Koehler Publishers, Inc., San Francisco

Lowther, J., (2004) „Kvaliteta hrvatskoga formalnog obrazovnog sustava”, Deloitte Touch Tohmats, Washington, http://www.ijf.hr/konkurentnost/lowther.pdf (3/16/2007) (Quality of Croatian Formal Education System)

Mumford, l. (1984) “Urban Prospect”, Peter Smith Pub Inc, Gloucester

Prava intelektualnog vlasništva (2009), Državni zavod za intelektualno vlasništvo, Zagreb 
(Intellectual Property Rights)

Pro-Inno-Europe (2006), http://www.proinno-eirope.eu/inno-metrics.html

Pulić, A., Sundać, D.(1998), Intelektualni kapital, IBCC, Rijeka

Serres, M. (1995), Éloge de la philosophie en langue française, Paris, France

Qvortrup L. (2004a), «The Hypercomplex Society», University of Southern, Denmark

Qvortrup L. (2004b): "The Third Space of Knowledge. Leadership and Creativity, Concluding remarks at the conference on Leadership and Creativity", Bramstrup, June

Rutenbeck, J. (2006), «Bit by Bit by Bit: Hypercomplexity and Digital Media Services», University of Denver, Ohio

Soete, L, (2007) "Notes on UIL-Related Policies of National Governments In: How Universities Promote Economic Growth", The World Bank, Washington

Sundać, D., et. al. (1997), Fleksibilnost i adaptibilnost, Novi pokazatelji uspješnosti poslovanja, IBCC, Rijeka (Flexibility and adaptability, new indicators of business)

Strategija razvitka Republike Hrvatske Hrvatska u 21. stoljeću (2003.) <www.hrvatska21. hr/znanost\%2030_6_2003.pdf>

Yusuf, S., Nabeshima, K. (2006), How Universities Promote Economic Growth (Directions in Development), World Bank Publications, Washington

European Union Delegation in Croatia (2011), <www.delhrv.ec.europa.eu>

7th Framework Program (2010.), <www.irb.hr/hr/fp7/rep/FP7.pdf>

- (2003) Zakon o patentu, Narodne novine, No. 173, Zagreb (Patent Act)

- (2003) Zakon o žigu, Narodne novine, No. 173, Zagreb (Trademark Act)

- (2005) Human Development Report 2005, UNDP, Oxford

- (2008) Human Development Report 2008, UNDP, Oxford

- (2008) World Development Indicators 2007, The World Bank, Washington

(2009) World Development Indicators 2008, The World Bank, Washington

(2010) World Development Indicators 2008, The World Bank, Washington

\section{APPENDIX}

Table 2: Research Capacity Index for Republic of Croatia and selected countries in 2007

\begin{tabular}{|c|c|c|c|c|c|}
\hline Country & $\begin{array}{l}\text { Investments in } \\
\text { Research and } \\
\text { Development } \\
\text { Index }\end{array}$ & $\begin{array}{l}\text { Investments } \\
\text { in Tertiary } \\
\text { Education } \\
\text { Index }\end{array}$ & $\begin{array}{l}\text { Number of } \\
\text { Scientific } \\
\text { Publications } \\
\text { Index }\end{array}$ & $\begin{array}{c}\text { Research } \\
\text { Capacity } \\
\text { Index }\end{array}$ & Rank \\
\hline
\end{tabular}

$\begin{array}{lccccc}\text { Israel } & 1,00000 & 0,710308 & 0,954685 & 0,888331 & 1 \\ \text { Sweden } & 1,00000 & 0,559778 & 0,983858 & 0,847878 & 2 \\ \text { Japan } & 0,823834 & 0,790723 & 0,8532 & 0,822586 & 3 \\ \text { U.S. } & 0,694301 & - & 0,916995 & 0,805648 & 4 \\ \text { Finland } & 0,911917 & 0,504054 & 0,963749 & 0,79324 & 5 \\ \text { Germany } & 0,650259 & 0,801417 & 0,883266 & 0,778314 & 6\end{array}$




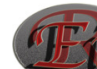

Switzerland

Canada

France

United

Kingdom

Netherlands

Austria

Australia

Belgium

Croatia

Cambodia

0,761658
0,520725
0,551813
0,453368

0,634715

0,463731

0,608808

0,458549

0,471503

$\mathbf{0 , 3 1 6 0 6 2}$

0,012953
0,540581

0,750566

0,749984

0,746585

0,500408

0,632456

0,541559

0,645389

0,55191

0,308393

0,000001

1,000000
0,93517
0,872152
0,928678

0,970194

0,949439

0,891364

0,931028

0,903262

$\mathbf{0 , 7 7 0 2 8 3}$

0,000001
0,767413

0,735487

0,72465

0,709543

0,701772

0,681875

0,680577

0,678322

0,642225

0,464913

0,004318

\section{7}

8

9

10

11

12

13

14

15

32

110

Source: authors calculations according to Human Development Report 2009, The World bank, Washington, 2009, p. 143.-201.; World Development indicators 2010., The World bank, Washington, 2009., p. 1-101., 197.-263.

Table 3: Technology and Innovation Efficiency Index for Republic of Croatia and selected countries in 2007

\begin{tabular}{lccccc}
\hline \multicolumn{1}{c}{ Country } & $\begin{array}{c}\text { Receipts from } \\
\text { Licensing Index }\end{array}$ & $\begin{array}{c}\text { Number } \\
\text { of Patents } \\
\text { Index }\end{array}$ & $\begin{array}{c}\text { Number of } \\
\text { Trademarks } \\
\text { Index }\end{array}$ & $\begin{array}{c}\text { Technology } \\
\text { and Innovation } \\
\text { Efficiency Index }\end{array}$ & Rank \\
U.S. & 0,910938 & 0,775263 & 0,915405 & 0,867202 & 1 \\
Japan & 0,877057 & 0,820000 & 0,856587 & 0,851215 & 2 \\
Korea & 0,719607 & 0,735507 & 0,844691 & 0,766602 & 3 \\
Germany & 0,783820 & 0,661866 & 0,810635 & 0,752107 & 4 \\
United & 0,918750 & 0,583693 & 0,721695 & 0,741380 & 5 \\
Kingdom & 0,825809 & 0,567577 & 0,804084 & 0,732490 & 6 \\
France & 0,821293 & 0,467229 & 0,694727 & 0,661083 & 7 \\
Canada & 0,678086 & 0,528482 & 0,762831 & 0,656466 & 8 \\
Australia & 0,953755 & 0,407113 & 0,534935 & 0,631934 & 9 \\
Finland & 0,637033 & 0,446582 & 0,792042 & 0,625219 & 10 \\
Spain & 0,894995 & 0,294928 & 0,581881 & 0,590601 & 11 \\
Singapore & 0,053190 & 0,714471 & 1,000000 & 0,589221 & 12 \\
China & 0,935795 & 0,341474 & 0,466600 & 0,581289 & 13 \\
Ireland & 0,804126 & 0,382234 & 0,534812 & 0,573724 & 14 \\
Israel & 0,682744 & 0,408344 & 0,628466 & 0,573185 & 15 \\
New Zealand & $\mathbf{0 , 5 6 8 0 8 5}$ & $\mathbf{0 , 2 7 9 0 4 1}$ & $\mathbf{0 , 4 5 9 1 8 9}$ & $\mathbf{0 , 4 3 5 4 3 8}$ & $\mathbf{3 1}$ \\
Croatia & 0,529494 & 0,271656 & 0,473990 & 0,425047 & 33 \\
Slovenia & 0,000001 & 0,213754 & 0,532433 & 0,248729 & 50 \\
Slovakia & 0,000001 & 0,284566 & 0,452211 & 0,245592 & 52 \\
Serbia & 0,095170 & 0,000001 & 0,000001 & 0,031723 & 110 \\
Bolivia & & & & \\
\hline Source: & & & & & \\
\hline
\end{tabular}

Source: authors calculations according to Human Development Report 2009, The World bank, Washington, 2009, p. 143.-201.; World Development indicators 2010., The World bank, Washington, 2009., p. 1-101., 197.-263. 
Table 4: Absorption of Knowledge and Technology Index for Republic of Croatia and selected countries in 2007

\begin{tabular}{lcccc}
\hline \multicolumn{1}{c}{ Country } & $\begin{array}{c}\text { Labour Force } \\
\text { Productivity } \\
\text { Index }\end{array}$ & GDPIndex & $\begin{array}{c}\text { Absorption of } \\
\text { Knowledge and } \\
\text { Technology Index }\end{array}$ & Rank \\
U.S. & 1,00000 & 1,00000 & 1,00000 & 1 \\
Norway & 0,97811 & 1,00000 & 0,98906 & 2 \\
Ireland & 0,97611 & 1,00000 & 0,98805 & 3 \\
Hong Kong & 0,97612 & 0,99600 & 0,98606 & 4 \\
Singapore & 0,95230 & 1,00000 & 0,97615 & 5 \\
Canada & 0,95185 & 0,98600 & 0,96892 & 6 \\
United Arab Emirates & 0,93530 & 1,00000 & 0,96765 & 7 \\
Denmark & 0,95335 & 0,97800 & 0,96567 & 8 \\
Switzerland & 0,94210 & 0,98900 & 0,96555 & 9 \\
Netherlands & 0,94132 & 0,98300 & 0,96216 & 10 \\
Australia & 0,95160 & 0,96800 & 0,95980 & 11 \\
Sweden & 0,94515 & 0,97300 & 0,95907 & 12 \\
Austria & 0,93537 & 0,98000 & 0,95768 & 13 \\
Finland & 0,94109 & 0,96700 & 0,95404 & 14 \\
United Kingdom & 0,93767 & 0,96600 & 0,95183 & 15 \\
Croatia & 0,73218 & 0,82800 & 0,78009 & 40 \\
Serbia & 0,52103 & 0,76000 & 0,64051 & 64 \\
Congo & 0,00000 & 0,17200 & 0,08600 & 110 \\
\hline
\end{tabular}

Source: authors calculations according to Human Development Report 2009, The World bank, Washington, 2009, p. 143.-201.; World Development indicators 2010., The World bank, Washington, 2009., p. 1-101., 197.-263. 


\section{HIPERKOMPLEKSNO ZNANJE U GOSPODARSTVU TEMELJENOM NA ZNANJU}

\section{Sažetak}

$U$ radu se definira hiperkompleksnost $i$ hiperkompleksno znanje u gospodarstvima temeljenim na znanju te se dokazuje hipoteza da razvitak, primjena i širenje novih tehnoloških dostignuća direktno utječu na ekonomski rast zemlje.

U izračunima su korišteni podaci prikupljeni iz relevantnih baza za 110 zemalja svijeta. Za ostale zemlje podaci nisu objavljeni što predstavlja tipično ograničenje u primjeni ovakve metodologije istraživanja.

Metodom transformacije varijabli utvrđena su razvojna zaostajanja Republike Hrvatske u promatranim razvojnim pokazateljima i njihovim komponentama te su dani prijedlozi za njihovo poboljšanje. S obzirom na utvrđenu vezu između porasta indeksa razvijenosti istraživačkih kapaciteta, učinkovitosti tehnologije i inovacija te sposobnosti apsorpcije znanja $i$ tehnologije na gospodarski rast, Hrvatska mora ulagati dodatna sredstva u povećanje ljudskog kapitala $i$ produktivnosti rada da bi smanjila razvojna zaostajanja.

Ključne riječi: hiperkompleksnost, društvo znanja, ekonomija znanja, ljudski potencijali, ekonomski razvoj

JEL klasifikacija: 010, 015, 033, D83 